Elsevier

$\mathrm{JAD} 00485$

\title{
Beta-blockers in anxiety disorders
}

\author{
Peggy E. Hayes ${ }^{1}$ and S. Charles Schulz ${ }^{2}$ \\ 'Department of Pharmacy and Pharmaceutics, Virginia Commonwealth University, Medical College of Virginia, Richmond, VA, U.S.A. \\ and ${ }^{2}$ Pharmacologic and Somatic Treatments Research Program, Schizophrenia Research Branch, Division of Clinical Research, \\ National Institute of Mental Health, Rockville, MD, U.S.A. \\ (Received December 1986) \\ (Accepted 6 May 1987)
}

\begin{abstract}
Summary
Studies evaluating the antianxiety and antipanic properties of $\beta$-blockers do not support their routine use in treating either generalized anxiety disorder or panic disorder. The use of propranolol for anxiety disorders accompanied by physical symptoms, especially cardiovascular complaints, may be effective in some patients when combined with benzodiazepines or perhaps in some non-responders to conventional treatment. Better designed studies are needed to evaluate the exact role of $\beta$-blocking agents in treating anxiety.

The efficacy of propranolol in patients with panic disorder has not been widely researched, but preliminary results have not been encouraging. Propranolol may provide symptomatic relief in some patients with residual somatic complaints (i.e., palpitations and tachycardia), when combined with the patient's ongoing drug regimen. Because $\beta$-blockers may induce depression, they should be used cautiously - if at all - in panic patients with concurrent depressive illness.
\end{abstract}

Key words: Beta-blockers; Anxiety disorder

\section{Introduction}

The use of $\beta$-adrenergic blocking drugs in the treatment of mental disorders began in 1966 when Granville-Grossman and Turner (1966) suggested that propranolol might be beneficial in managing the physical symptoms of anxiety, especially cardiovascular complaints. Additional reports evaluating the efficacy of $\beta$-blockers in anxiety

Address for correspondence: Dr. Peggy E. Hayes, Medical College of Virginia, School of Pharmacy, Box 581 MCV Station, Richmond, VA 23298, U.S.A. states (Wheatley 1969; Bonn et al. 1972; Ramsey et al. 1973; Tyrer and Lader 1973, 1974a, b; Kellner et al. 1974; Silverstone 1974; Becker 1976; Burrows et al. 1976; Johnson et al. 1976; Tanna et al. 1977; Kathol et al. 1980) and panic disorder (Noyes et al. 1984; Shehi and Patterson 1984; Munjack et al. 1985) have been published and several review articles have been written (Whitlock and Price 1974; Greenblatt and Shader 1978; Cole et al. 1979; Tyrer 1980; Noyes 1982, 1985; Hayes and Schulz 1983). However, the efficacy and exact therapeutic role of $\beta$-blocking drugs in treating generalized anxiety disorder and panic disorder 
remain unestablished. In this paper we will review the pharmacology of $\beta$-blocking agents and examine theories which indicate that they may be useful for the treatment of anxiety. Then we will critically review the clinical studies and suggest guidelines for clinical use.

\section{Anxiety disorders}

According to the recently revised edition of the Diagnostic and Statistical Manual of the American Psychiatric Association (1987) (DSM-III-R), anxiety disorders are classified into several different subtypes (e.g., generalized anxiety disorder, panic disorder with agoraphobia, phobic disorders, obsessive-compulsive disorder, and posttraumatic stress disorder). Anxiety disorders are among the most common mental disorders encountered in clinical practice. About $16 \%$ of the population will have an anxiety disorder at some point during their lives, with more illness in women than men (Myers et al. 1984). Types of anxiety disorders possibly responsive to $\beta$-blockers include generalized anxiety disorder, panic disorder with agoraphobia, and social phobia (Dommisse and Hayes 1987).

Generalized anxiety disorder is characterized by persistent disabling anxiety of at least 6 months with at least six symptoms present. Symptoms involve the areas of motor tension, autonomic hyperactivity, vigilance and scanning, and apprehensive expectation (DSM-III-R). Benzodiazepines are currently the drugs of choice for the treatment of generalized anxiety disorder (Dommisse and Hayes 1987). Most well-controlled, short-term studies of benzodiazepines indicate that they are effective in decreasing both the subjective and physiologic symptoms of anxiety (Greenblatt and Shader 1978). However, $\beta$-blockers have been recommended as a specific treatment for the physical symptoms of anxiety (Granville-Grossman and Turner 1966; Tyrer and Lader, 1974a, b).

Panic disorder begins as a series of acute or unprovoked (spontaneous) anxiety attacks, involving an intense, terrifying fear. Patients of ten describe an overwhelming sense of doom, a fear of dying or losing control, and a host of physical symptoms, suggestive of autonomic hyperactivity. Panic attacks last no more than 20-30 min, with the most intense symptoms within the first $10 \mathrm{~min}$. In most patients the disease is progressive and patients often develop anticipatory (chronic) anxiety. Eventually, patients will avoid specific situations (e.g., crowded places, stores, bridges, and traveling away from home) where they fear that a panic attack may occur and where help is not readily available or escape possible. When phobic avoidance (or agoraphobia) becomes widespread (i.e., includes many public places or travel away from home) and increasing constricting of activities is evident, the diagnosis of panic disorder with agoraphobia is made (DSM-III-R). Effective therapeutic agents in the treatment of panic disorder or agoraphobia with panic attacks include the tricyclic antidepressant imipramine, the monoamine oxidase inhibitor phenelzine, and the benzodiazepine alprazolam (Ballenger 1986; Dommisse and Hayes 1987). Propranolol is occasionally recommended, in combination with an antipanic agent, for patients who continue to have difficulty with palpitations (Ballenger 1986).

Social phobia is a type of phobic disorder that is characterized by a persistent, irrational fear of behaving in an embarrassing or humiliating manner in public when the individual is the focus of others' attention (DSM-III-R). Although there is no established treatment for social phobia, some patients respond to $\beta$-blocking agents. Evidence to support the use of $\beta$-blockers comes from reports of their positive effects on performance anxiety (Dommisse and Hayes 1987). Administration of $40 \mathrm{mg}$ propranolol $1 \mathrm{~h}$ before a performance may be quite helpful, since physical symptoms of anxiety frequently add to the patient's distress. The only controlled study of propranolol in a clinic population of social phobics did not report a positive drug response, but only 15 patients were studied (Fallon et al. 1981).

Symptoms of anxiety are both psychological (tension. fear, difficulty concentrating, and apprehension) and somatic (tachycardia, palpitations, tremor, sweating, and gastrointestinal upset) (DSM-III-R). For some patients, the most troublesome and disabling symptoms are somatic. Physiologic changes often include an increase in pulse rate, systolic blood pressure, muscle activity and respiratory rate; a decrease in salivation and finger pulse volume, diaphoresis, and mydriasis. 
Patients with panic disorder report somatic symptoms, especially cardiovascular, more frequently than do patients with generalized anxiety disorder (Anderson et al. 1984). Beta-blocking drugs may be effective, used alone or in combination with an anxiolytic or antipanic agent, in some patients with somatic symptoms of anxiety.

\section{Pharmacology of $\beta$-adrenergic blocking agents}

In 1948, Ahlquist classified receptors of the sympathetic (adrenergic) nervous system into two types, $\alpha$ and $\beta$, according to the response of various tissues to sympathomimetic amines. Betareceptors are further subdivided into $\beta_{1}$ (cardiac) and $\beta_{2}$ (vascular, bronchial and gastrointestinal smooth muscle) (Lands et al. 1967). Beta-receptors have been identified in the central nervous system (CNS).

In 1964 propranolol, the first non-selective $\beta$ adrenergic blocking agent, was introduced (Black et al. 1964). In 1968 propranolol was marketed in the United States for the treatment of cardiac arrhythmias. Examples of $\beta$-blockers currently marketed for oral use include both cardioselective drugs (e.g., metoprolol (Lopressor) and atenolol (Tenormin)) and non-selective drugs (e.g., pindolol (Visken), oxprenolol (Trasicor), nadolol (Corgard) and timolol (Blocadren)). Beta-blocking agents are used successfully for a growing number of medical problems (e.g., essential hypertension, angina pectoris, cardiac arrhythmias, hypertrophic obstructive cardiomyopathy, pheochromocytoma, migraine). They are also used for the prevention of reinfarction and sudden death in selected myocardial infarction patients.

The most important therapeutic effects of these drugs are on the $\beta_{1}$ (cardiac) receptors. Propranolol decreases heart rate and cardiac output and slightly decreases blood pressure in resting subjects. The effects on cardiac output and heart rate are more dramatic during exercise (Weiner 1985).

Non-selective $\beta$-blockers have considerable effects on the bronchi and bronchioles. Bronchodilation is mediated by $\beta_{2}$-receptors and blocking these receptors increases airway resistance. Although this is not clinically important in normal individuals, it can be marked and can result in bronchospasm in asthmatics. Propranolol inter- feres with insulin secretion and glycogenolysis. These agents should be used with caution in patients prone to hypoglycemia and in diabetics (Weiner 1985). Cardioselective $\beta$-blocking drugs, in low doses, may be preferred; however, at higher doses cardioselective drugs lose their specificity and will inhibit $\beta_{2}$-receptors.

\section{Pharmacokinetics}

The pharmacokinetic properties of $\beta$-blockers vary and have been previously reviewed (Routledge and Shand 1979; Gengo and Green 1986). After oral administration, propranolol is a lipophilic alkaline compound that is almost completely absorbed. Approximately $60-70 \%$ of the drug is metabolized during its first pass through the liver and only $30.40 \%$ of the drug is bioavailable (Wood et al. 1978). Individual variability in the degree of first-pass elimination contributes to the great difference in plasma concentrations after oral administration of equivalent doses. The halflife of propranolol after chronic oral administration averages about $4 \mathrm{~h}$; multiple daily dosing is required (Wood et al. 1978; Gengo and Green 1986).

An important pharmacokinetic difference in the $\beta$-blockers is that some are predominantly metabolized by hepatic mechanisms (propranolol, metoprolol, timolol) and others are climinated by renal mechanisms (nadolol and atenolol). Pindolol depends equally upon hepatic and renal mechanisms for elimination and drug accumulation occurs when either mechanism is impaired. The bioavailability of propranolol, metoprolol, and timolol would be expected to increase in patients with renal insufficiency and drug accumulation occurs (Gengo and Green 1986).

The lipid solubility of $\beta$-blockers is an important factor in predicting the extent and rate of drug distribution into the CNS. Propranolol, metoprolol, alprenolol, and pindolol are highly lipid soluble and show a significant delay in reaching CNS receptor sites and are removed more slowly than the more lipid soluble drugs. When taken chronically, all $\beta$-blockers show significant distribution into the CNS (Gengo and Green 1986). 
Noradrenergic hypothesis and mechanism of action of $\beta$-blockers in anxiety disorders

Since the early work of Cannon (1927), researchers have associated symptoms of anxiety with a central sympathetic or noradrenergic nervous system discharge. In addition, anxious patients clearly display symptoms indicating peripheral noradrenergic hyperactivity (e.g., hyperventilation, palpitations, and tremulousness). The relationship of these peripheral symptoms to the central etiology of anxiety is unknown. Because $\beta$-blockers are known to decrease noradrenergic activity, they have been investigated as a possible treatment for anxiety disorders. It is well established that $\beta$-blockers possess both central and peripheral $\beta$-blockade. Recently, $\beta$-blockers have been shown to antagonize other neurotransmitters, including serotonin (Gardner 1985).

In an effort to further test the noradrenergic model of anxicty, researchers have administered drugs that specifically affect certain neurotransmitters to animals, healthy subjects, and patients. Although effects of intravenous norepinephrine, epinephrine, and the $\beta$-adrenergic receptor agonist, isoproterenol, have been studied in anxious patients, results are confusing and difficult to interpret because of the poor CNS penetration of the substances used (Charney et al. 1984). Other agents have produced more promising results. For example, low doses of $\beta$-carboline-3-carboxylic acid ethyl ester $(\beta-C C E)$, a benzodiazepine receptor antagonist, produce a response in monkeys similar to the effects experienced in anxious patients and normal subjects during stressful situations. These pharmacodynamic effects of $\beta$-CCE (e.g., behavioral agitation, elevated plasma cortisol levels, blood pressure, and heart rate) were blocked by pretreatment with diazepam, but pretreatment with propranolol blocked only the increase in heart rate. Therefore, increased heart rate, a somatic component of anxiety, may be selectively affected by propranolol (Insel et al. 1984).

Redmond (1977) provided evidence that the small brain stem nucleus (the locus ceruleus (LC)) may be involved in the body's arousal response and may play a major role in regulating anxiety. The LC contains $70 \%$ of the brain's noradrenergic neurons and has widespread projections to the limbic system as well as the cerebral and cerebellar cortices. The $\alpha_{2}$-adrenergic autoreceptor located presynaptically on neuronal cell bodies or terminals regulates the release of norepinephrine from the locus ceruleus and the lateral tegmentum through a negative feedback mechanism. Drugs with antianxiety or antipanic effects (e.g., benzodiazepines and antidepressants) inhibit LC activity (decrease norepinephrine release). The exception is buspirone, a recently approved non-benzodiazepine anxiolytic, that increased I.C neuronal impulse flow (Charney et al. 1984).

The most convincing evidence to support the role of the noradrenergic system in anxiety disorders involves studies of patients with panic disorder. Several clinical investigations support the hypothesis that panic disorder patients have altered noradrenergic function. These patients are clearly more susceptible to agents that stimulate I.C activity. Charney and associates (1984) reported that yohimbine produced significantly greater increases in anxiety, nervousness, palpitations, restlessness, tremors, and sitting systolic blood pressure in patients than in healthy subjects. Yohimbine blocks the presynaptic $\alpha_{2}$-adrenergic autoreceptor and causes a robust increase in brain epinephrine. In the panic patients studied, a subsensitive or abnormal presynaptic $\alpha$-receptor may have produced the enhanced response to yohimbine.

Charney and Heninger (1986) recently reported that patients with panic disorder, when given clonidine, had a significantly greater decrease in plasma 3-methoxy-4-hydroxyphenylglycol levels (the major metabolite of norepinephrine) and sitting and standing diastolic blood pressure than normal controls. Clonidine is an $\alpha_{2}$-adrenergic receptor agonist that decreases noradrenergic function. This finding lends support to the theory that the regulation of noradrenergic activity is aberrant in some panic patients. Further evidence was supplied by Neese et al. (1984) who reported that patients with panic attacks had increased adrenergic activity as compared with normal subjects, as evidenced by increased resting heart rate, endocrine measurements, and plasma norepinephrine levels, at times other than during the panic attacks. However, the heart rate increase after a dose of isoproterenol was less for patients. The 
authors proposed that postsynaptic $\beta$-adrenergic receptor may be decreased or down-regulated in panic patients.

Intravenous sodium lactate infusions may trigger actual panic attacks in patients with panic disorder but not normal controls (Liebowitz et al. 1984). After successful treatment with antidepressants, lactate-induced panic attacks were blocked (Liebowitz et al. 1984). However, Gorman et al. (1983) reported that pretreatment with propranolol infusion failed to affect lactate-induced panic attacks, tachycardia, and systolic blood pressure, or to reduce baseline anxiety. Although the dose of propranolol was enough to produce peripheral blockade, it may not have been enough to block brain or central $\beta$-adrenergic receptors. In addition, the effect of acute, not long-term, $\beta$-blockade on lactate-induced panic was studied. Liebowitz et al. (1986) found no evidence to support the theory that a rapid increase in plasma norepinephrine may cause lactate-induced panic attacks, although increased epinephrine may be a predisposing factor. This could explain why acute $\beta$-adrenergic blockade was found ineffective in blocking lactate-induced panic.

Thus, most studies generally support a relationship between panic disorder and abnormal regulation of brain norepinephrine. It appears that the presynaptic $\alpha_{2}$-autoreceptor and/or the regulatory inputs to noradrenergic neurons may be dysfunctional in some patients. Therefore, if the noradrenergic abnormality present in panic disorder patients involves the presynaptic $\alpha_{2}$-adrenergic neuron, it might be unreasonable to expect $\beta$-blockers to prevent panic attacks. In treating certain physical symptoms of anxiety, it is not known if $\beta$-blocking agents act by blocking only peripheral $\beta$-mediated sites or by some central effect (either on $\beta$-receptors or through some other non- $\beta$-receptor mechanism). Most clinical and animal studies reviewed still support mainly a peripheral $\beta$-blocking effect, as will be noted in the review of clinical efficacy.

\section{General guidelines for the clinical evaluation of antianxiety drugs}

Like all psychiatric illnesses, anxiety disorders are difficult syndromes in which to evaluate treat- ment outcomes. The diversity of presenting symptoms, a tendency of the illness to spontaneously remit, a large number of placebo responders, and a lack of objective diagnostic criteria make study design and methodology critical to obtaining meaningful and valid outcome data (FDA 1977). In assessing the role of $\beta$-blockers in treating generalized anxiety disorder, we reviewed only randomized, double-blind studies that included a placebo or standard antianxiety agent control group.

Obtaining a homogeneous study population is one of the greatest problems in psychotropic drug research. Patient selection criteria should be specified; when subjects are selected by diagnosis, then the diagnostic criteria should be stated (FDA 1977). The reviewed studies used a 'mixed' or heterogeneous patient population having both acute and chronic anxiety, with varying degrees of severity and duration of the illness (Tables 1 and 2). Two studies specified their patient selection criteria (Tanna et al. 1977; Kathol et al. 1980). Mixing subtype of anxious patients serves to produce conflicting data and makes analysis of results a difficult and tenuous task.

Because of the large number of placebo responders, anxious patients should receive a drug-free placebo washout before the active drug phase begins. If the symptoms spontaneously remit, the patient should be eliminated from the study (FDA 1977). Only four studies used a placebo washout phase (Johnson et al. 1976; Burrows et al. 1976; Tanna et al. 1977; Kathol et al. 1980). Additional medications, especially psychotropic drugs, should be avoided during the study as their impact on the therapeutic outcome and the side effect profile of the investigational drug cannot be quantified. Four studies stated that several patients did receive concurrent medications during the study phase (Bonn et al. 1972; Tyrer and Lader 1973; Johnson et al. 1976; Kathol et al. 1980); the remaining studies failed to address the issue of concurrent medications.

Eight of the studies reviewed used a crossover study design (Granville-Grossman and Turner 1966; Bonn et al. 1972; Ramsey et al. 1973; Tyrer and Lader 1973, 1974a; Kellner et al. 1974; Tanna et al. 1977; Kathol et al. 1980). This design uses each subject as his own control and is more sensi- 
TABLE 1

DOLBLE-BLIND EFFICACY STUDIES ASSESSING PROPRANOIOL IN ANXIFTY DISORDFRS

\begin{tabular}{|c|c|c|c|c|c|c|c|c|}
\hline Authors & Diagnosis & $\begin{array}{l}\text { Number } \\
\text { of pa- } \\
\text { tients } \\
\text { com- } \\
\text { pleting } \\
\text { trial }\end{array}$ & Dosage " & $\begin{array}{l}\text { Study } \\
\text { duration } \\
\text { (weeks) }\end{array}$ & $\begin{array}{l}\text { Psychological } \\
\text { assessment }\end{array}$ & $\overline{\text { Results }}^{n}$ & & Comments ${ }^{c, d}$ \\
\hline $\begin{array}{l}\text { Granville- } \\
\text { Cirossman } \\
\text { and Turner } \\
(1966)\end{array}$ & $\begin{array}{l}\text { Most prominent } \\
\text { symptoms were } \\
\text { anxiety }\end{array}$ & 15 & $\begin{array}{l}\text { PPL } 80 \mathrm{mg} \\
\text { Placeho }\end{array}$ & 1 & $\begin{array}{l}\text { Physician's pre- } \\
\text { ference } \\
\text { Physician's } \\
\text { rating anxiety } \\
\text { Patient's self } \\
\text { rating autonomic } \\
\text { Patient's mental } \\
\text { symptoms } \\
\text { Patient's other } \\
\text { physical symptoms }\end{array}$ & $\begin{array}{l}+ \\
+ \\
+ \\
- \\
-\end{array}$ & & $\begin{array}{l}\text { PPI may prove } \\
\text { to be more bene- } \\
\text { ficial in patients } \\
\text { whose symptoms } \\
\text { are duc to auto- } \\
\text { nomic stimu- } \\
\text { lation }\end{array}$ \\
\hline $\begin{array}{l}\text { Wheatley } \\
(1969)\end{array}$ & $\begin{array}{l}\text { Acute and chronic } \\
\text { anxiety neurosis }\end{array}$ & 84 & $\begin{array}{l}\text { PPL } 90 \mathrm{mg} \\
\text { CLX } 30 \mathrm{mg}\end{array}$ & 6 & $\begin{array}{l}\text { Physician's global } \\
\text { rating } \\
\text { General prac- } \\
\text { titioners' research } \\
\text { group } \\
\text { Patient's self } \\
\text { rating }\end{array}$ & $\begin{array}{l} \pm \\
\pm \\
\pm\end{array}$ & & $\begin{array}{l}\text { CDX was slightly } \\
\text { better. No placebo } \\
\text { control. Parallel } \\
\text { study design }\end{array}$ \\
\hline $\begin{array}{l}\text { Ramscy el al. } \\
(1973)\end{array}$ & $\begin{array}{l}\text { Neurotic anxiety. } \\
\text { and thyrotoxicosis } \\
\text { with anxiety }\end{array}$ & $\begin{array}{l}14 \\
12\end{array}$ & $\begin{array}{l}\text { PPL } 160 \mathrm{mg} \\
\text { Placcbo }\end{array}$ & 2 & $\begin{array}{l}\text { Physician's } \\
\text { global rating } \\
\text { Paticnt's self } \\
\text { rating }\end{array}$ & $\begin{array}{l}- \\
-\end{array}$ & & $\begin{array}{l}\text { PPL not effective } \\
\text { for the 'central' } \\
\text { symptoms of } \\
\text { anxiety }\end{array}$ \\
\hline $\begin{array}{l}\text { Kellner } \\
(1974)\end{array}$ & $\begin{array}{l}\text { A mixture of } \\
\text { non-psychotic } \\
\text { anxiety disorders }\end{array}$ & 22 & $\begin{array}{l}\text { PPL 80- } \\
160 \mathrm{mg} \\
\text { Placebo }\end{array}$ & 1 & $\begin{array}{l}\text { Physician's and } \\
\text { patient's global } \\
\text { rating } \\
\text { Hamilton anxicty } \\
\text { Symptom rating } \\
\text { Brief distress } \\
\text { scale } \\
\text { Symptom ques- } \\
\text { tionnaire }\end{array}$ & $\begin{array}{l}- \\
- \\
- \\
-\end{array}$ & & $\begin{array}{l}\text { PPL has no signifi- } \\
\text { cant 'short-term' } \\
\text { antianxiety effects }\end{array}$ \\
\hline $\begin{array}{l}\text { Tyrer } \\
\text { and Lader } \\
(1974 a, b)\end{array}$ & $\begin{array}{c}\text { Chronic anxiety } \\
\text { Psychic }=6 \\
\text { Somatic }=6\end{array}$ & 12 & $\begin{array}{l}\text { PPL 120- } \\
360 \mathrm{mg} \\
\text { DZ 6-18 } \mathrm{mg} \\
\text { Placebs }\end{array}$ & 1 & $\begin{array}{l}\text { Hamilton anxiety } \\
\text { Psychic } \\
\text { Somatic } \\
\text { Patient's preference } \\
\text { Psychic } \\
\text { Somatic }\end{array}$ & $\begin{array}{l}\text { D7 } \\
+ \\
+ \\
+ \\
+\end{array}$ & $\begin{array}{l}\text { PPL } \\
- \\
+ \\
+ \\
+\end{array}$ & $\begin{array}{l}\text { DZ was the most ef- } \\
\text { fective treatment. } \\
\text { PPL may be con- } \\
\text { fined to patients } \\
\text { 'complaining' of } \\
\text { physical symptoms }\end{array}$ \\
\hline $\begin{array}{l}\text { Becker } \\
(1976)\end{array}$ & $\begin{array}{l}\text { Acute or chronic } \\
\text { anxiety with or } \\
\text { without depression }\end{array}$ & 46 & $\begin{array}{l}\text { PPL } 240 \mathrm{mg} \\
\text { OPL } 240 \mathrm{mg}\end{array}$ & 2 & $\begin{array}{l}\text { Physician's and } \\
\text { patient's global } \\
\text { rating } \\
\text { Physician's rating } \\
\text { of symptoms } \\
\text { Visual analogue } \\
\text { scale }\end{array}$ & $\begin{array}{l} \pm \\
\pm \\
\pm\end{array}$ & & $\begin{array}{l}\text { No placebo control, } \\
\text { used parallel study } \\
\text { design }\end{array}$ \\
\hline
\end{tabular}


TABLE 1 (continued)

\begin{tabular}{|c|c|c|c|c|c|c|c|c|c|}
\hline Authors & Diagnosis & $\begin{array}{l}\text { Number } \\
\text { of pa- } \\
\text { tients } \\
\text { com- } \\
\text { pleting } \\
\text { trial }\end{array}$ & Dosage ${ }^{a}$ & $\begin{array}{l}\text { Study } \\
\text { duration } \\
\text { (weeks) }\end{array}$ & $\begin{array}{l}\text { Psychological } \\
\text { assessment }\end{array}$ & Result & & & Comments $c, d$ \\
\hline $\begin{array}{l}\text { Tanna et al. } \\
(1977)\end{array}$ & $\begin{array}{l}\text { Moderate to } \\
\text { severe chronic } \\
\text { anxiety neurosis }\end{array}$ & $26^{f}$ & $\begin{array}{l}\text { PPL } 40 \mathrm{mg} \\
\text { PPl. } 120 \mathrm{mg} \\
\text { Placebo }\end{array}$ & 1 & $\begin{array}{l}\text { 17-item symptom } \\
\text { checklist } \\
\text { PPL } 40 \mathrm{mg} \\
\text { Placebo } \\
\text { PPL } 120 \mathrm{mg}\end{array}$ & $\begin{array}{l}\text { wk } 1 \\
- \\
-\end{array}$ & $\begin{array}{l}\text { wk } 2 \\
- \\
-\end{array}$ & $\begin{array}{l}\text { wk } 3 \\
+ \\
+\end{array}$ & $\begin{array}{l}\text { PPL } 120 \text { mg was } \\
\text { ineffective when } \\
\text { given during week } 1 \text {, } \\
\text { but was effective } \\
\text { during week } 3\end{array}$ \\
\hline $\begin{array}{l}\text { Kathol et al. } \\
(1980)\end{array}$ & $\begin{array}{l}\text { Mixture of } \\
\text { chronic anxiety } \\
\text { disorders, DSM-III }\end{array}$ & 26 & $\begin{array}{l}\text { PPL } 160 \mathrm{mg} \\
\text { Placebo }\end{array}$ & 2 & $\begin{array}{l}\text { Hamilton anxicty } \\
\text { Physician's global } \\
\text { rating } \\
\text { SLE-90 (anxiety) } \\
\text { SLE-90 (somatic) } \\
\text { Symptom severity } \\
\text { Symptom relief } \\
\text { Patient's glohal } \\
\text { rating }\end{array}$ & $\begin{array}{l}- \\
+ \\
+ \\
+ \\
+ \\
+ \\
+ \\
+\end{array}$ & & & $\begin{array}{l}\text { Five patients trok } \\
\text { psychotropic drugs } \\
\text { during the study. } \\
\text { Psychic and cardio- } \\
\text { vascular symptoms } \\
\text { improved }\end{array}$ \\
\hline
\end{tabular}

" PPL = propranolol CDX $=$ chlordiazepoxide; $\mathrm{DZ}-$ diazepam; OPL $=$ oxprenolol.

$\mathrm{b}+=$ significant advantage for propranolol $(P<0.05) ; \pm=$ patient improved on both treatments. no significant difference between active drugs; $-=$ no drug effects $(P>0.05)$.

c Study design was crossover unless otherwise stated.

'All patients were outpatients unless otherwise stated.

e Diazepam was significantly more effective than propranolol or placebo.

' Included six inpatients.

tive than parallel or independent group design for highly drug specific disorders (e.g., hypertension). However, anxiety disorders are not considered highly drug specific. Therefore, a crossover design may be actually less useful than a parallel design (Goldberg and Hamer 1983). A major disadvantage of the crossover design is the influence that the order of treatment administration may have on study results (Goldberg and Hamer 1983). In dealing with anxious patients whose clinical state may spontaneously improve, the second treatment (phase 2) could perform better than the first, if subjects entering phase 2 have not returned to their baseline functioning. None of the studies reviewed incorporated a washout phase between treatments. Therefore, it is not possible to assess the effects of order and the possible carry over effects upon the final treatment outcome.

It is important that an adequate dosage of medication be administered long enough to obtain maximal therapeutic response. For antianxiety agents, this can usually be determined in trials of
2-4 weeks' duration (FDA 1977). Five of the 13 studies evaluated used an inadequate study duration of 1 week (Granville-Grossman and Turner 1966; Kellner et al. 1974; Tyrer and Lader, 1974a, b; Tanna et al. 1977). The antianxiety dosage of propranolol has not been defined. Because of variable drug bioavailability, therapeutic dosages may be expected to vary widely among patients. Small fixed amounts of less than $100 \mathrm{mg}$ of propranolol or its equivalent, used in some studies, may have been inadequate for the majority of patients (Granville-Grossman and Turner 1966; Wheatley 1969; Silverstone 1974; Tanna et al. 1977).

Methods for evaluating antianxiety drug effects should include both global and standardized rating scales (FDA 1977). Global ratings are the easiest to obtain, are probably the most clinically relevant, but they are the least specific. Target symptom ratings are more specific but less reliable. When the two measures do not agree, the global rating is considered the more accurate. Ideally, these scales should be completed by both the 
TABLE 2

DOUBLE-BLIND EFFICACY STLDIES ASSESSING OTHER $\beta$-BLOCKERS IN ANXIETY DISORDERS

\begin{tabular}{|c|c|c|c|c|c|c|c|c|}
\hline Authors & Diagnosis & $\begin{array}{l}\text { Number of } \\
\text { patients } \\
\text { completing } \\
\text { trial }\end{array}$ & Dosage & $\begin{array}{l}\text { Study } \\
\text { duration } \\
\text { (weeks) }\end{array}$ & $\begin{array}{l}\text { Psychological } \\
\text { assessment }\end{array}$ & \multicolumn{2}{|c|}{ Results } & Comments $^{\text {h.c }}$ \\
\hline $\begin{array}{l}\text { Bonn et al. } \\
\text { (1972) }\end{array}$ & $\begin{array}{l}\text { Most promi- } \\
\text { nent symptom } \\
\text { was anxiety }\end{array}$ & 15 & $\begin{array}{l}\text { Practolol } \\
400 \mathrm{mg} \\
\text { Placebo }\end{array}$ & 2 & $\begin{array}{l}\text { Physician's } \\
\text { preference }\end{array}$ & + & & $\begin{array}{l}\text { Thirteen patients } \\
\text { were taking other } \\
\text { drugs during the } \\
\text { first visit and } \\
\text { three continued } \\
\text { these drugs } \\
\text { throughout the } \\
\text { study }\end{array}$ \\
\hline $\begin{array}{l}\text { Tyrer and } \\
\text { Lader (1973) }\end{array}$ & $\begin{array}{l}\text { Chronic } \\
\text { anxicty } \\
\text { for } 6 \text { months }\end{array}$ & 14 & $\begin{array}{l}\text { Sotalol } \\
80-400 \mathrm{mg} \\
\text { Placeho }\end{array}$ & 2 & $\begin{array}{l}\text { Physician's } \\
\text { preference } \\
\text { Hamilton } \\
\text { anxiety } \\
\text { Patient's } \\
\text { preference }\end{array}$ & $\begin{array}{l}+ \\
+ \\
-\end{array}$ & & $\begin{array}{l}\text { Three patients took } \\
\text { sedative medica- } \\
\text { tion. Patients } \\
\text { rated sotalol as no } \\
\text { more effective than } \\
\text { placebo }\end{array}$ \\
\hline $\begin{array}{l}\text { Silverstone } \\
(1974)\end{array}$ & $\begin{array}{l}\text { Symptoms } \\
\text { attributed to } \\
\text { anxicty }\end{array}$ & 68 & $\begin{array}{l}\text { Oxprenolol } \\
60 \mathrm{mg} \\
\text { Benzoctamine } \\
30 \mathrm{mg} \\
\text { Oxprenolol } \\
60 \mathrm{mg} \text { and } \\
\text { Benzoctamine } \\
30 \mathrm{mg} \\
\text { Placebo }\end{array}$ & 4 & $\begin{array}{l}\text { Physician's } \\
\text { global rating } \\
\text { Morbid } \\
\text { anxiety scale }\end{array}$ & $\begin{array}{l}- \\
-\end{array}$ & $\mathrm{OXP}$ & $\begin{array}{l}\text { No significant dif- } \\
\text { ferences were found } \\
\text { betwetn the four } \\
\text { treatments. Paral- } \\
\text { lel study design }\end{array}$ \\
\hline & & & & & & $\mathrm{D} Z$ & $\mathrm{OXP}$ & \\
\hline $\begin{array}{l}\text { Burrows et } \\
\text { al. (1976) }\end{array}$ & $\begin{array}{l}\text { Moderately } \\
\text { severe } \\
\text { anxiety } \\
\text { symptoms }\end{array}$ & 62 & $\begin{array}{l}\text { Oxprenolol } \\
80-560 \mathrm{mg} \\
\text { Diazepam } \\
5-35 \mathrm{mg} \\
\text { Placebo }\end{array}$ & 3 & $\begin{array}{l}\text { Physician's } \\
\text { global rating } \\
\text { Hamilton } \\
\text { anxiety } \\
\text { Target } \\
\text { symptoms } \\
\text { Physician's } \\
\text { preference }\end{array}$ & $\begin{array}{l} \pm \\
- \\
- \\
-\end{array}$ & $\begin{array}{l} \pm \\
- \\
- \\
-\end{array}$ & $\begin{array}{l}\text { Patients improved } \\
\text { significantly on } \\
\text { all three treat- } \\
\text { ments. No evidence } \\
\text { that oxprenolol is } \\
\text { specific for } \\
\text { 'somatic' anxiety. } \\
\text { Parallel study } \\
\text { design }\end{array}$ \\
\hline
\end{tabular}

a.b.c See Table 1. 
investigator and the patient. Criteria for determining response and non-response should be specified in the study protocol (FDA 1977). As shown in Tables 1 and 2, measurements used to evaluate the antianxiety properties of $\beta$-blockers frequently produced conflicting results. Since these studies did not specify their criteria for determining response and non-response, interpretation of the data was limited.

Five well designed and executed controlled studies of $30-50$ patients per treatment group should be sufficient to demonstrate drug-placebo differences and drug efficacy (FDA 1977). Since a majority of the studies reviewed used a sample size of less than 20 and had numerous design problems, drug-placebo differences and drug efficacy have not been adequately established. This is a problem especially for small studies reporting negative results.

\section{Double-blind studies assessing propranolol in generalized anxiety disorders}

Studies designed to assess the efficacy of propranolol as an antianxiety agent have produced conflicting results, and no definite statement regarding efficacy is possible (Table 1). Of the five studies that compared the antianxiety effects of propranolol to placebo, two studies found no detectable difference between treatments (Ramsey et al. 1973; Kellner et al. 1974), and three studies produced conflicting results (Granville-Grossman and Turner 1966; Tanna et al. 1977; Kathol et al. 1980). Two studies tended to 'favor' propranolol over placebo, but this observation was limited to anxious patients presenting with physical symptoms (e.g., tremor, palpitations, diaphoresis, or diarrhea) (Granville-Grossman and Turner 1966; Kathol et al. 1980).

Two studies evaluated the antianxiety properties or propranolol versus an active antianxiety drug (Wheatley 1969; Becker 1976). Both drugs were found to be equally effective. In addition, two studies compared the efficacy of propranolol to that of diazepam or placebo (Tyrer and Lader, 1974a, b); diazepam was the most effective treatment.

Recently, a placebo-controlled crossover study was undertaken to evaluate the therapeutic benefit of adding propranolol to diazepam in chronically anxious outpatients (Hallstrom et al. 1981). Twenty-four patients received four treatments in succession for 2 weeks. The author concluded that: (a) diazepam is more effective than placebo in treating chronic anxiety; (b) propranolol alone was less effective than placebo; (c) the addition of propranolol to diazepam significantly improved the outcome for psychic but not somatic symptoms; and (d) chronically anxious patients derive little benefit from continued antianxiety drug therapy. Additional studies are needed to clearly establish the additive effects of propranolol and diazepam therapy.

\section{Double-blind studies assessing other $\beta$-blockers in generalized anxiety disorder}

Five studies have evaluated the antianxiety effects of other $\beta$-blockers versus placebo or an antianxiety agent (Table 2). Positive results were reported for practolol versus placebo, but only one rating scale was used to assess response, and 13 of the 15 patients were taking other medications (Bonn et al. 1972). The study of sotalol versus placebo produced 'mixed' findings, with patients rating sotalol as no more effective than placebo (Tyrer and Lader 1973). The remaining three studies evaluated the efficacy of oxprenolol versus placebo or an active antianxiety drug; they were unable to report a significant difference between oxprenolol and placebo (Silverstone 1974; Burrows et al. 1976; Johnson et al. 1976).

\section{Studies of propranolol in panic disorder and agoraphobia}

Because of the large number of physical symptoms, especially palpitations and tachycardia, present during an acute panic attack, it seems reasonable that $\beta$-blockers may reduce or eliminate the adrenergic discharge associated with panic attacks.

Shehi and Patterson (1984) reported the successful treatment of 16 patients with panic attacks as defined by DSM-III with alprazolam (1.5- 3.0 $\mathrm{mg}$ ) combined with propranolol $(40-160 \mathrm{mg})$. Panic attacks were blocked at lower doses of each drug with the combination. Many patients re- 
mained stabilized during a 9-18 month follow-up while receiving low doses of alprazolam, propranolol, or both. This is a non-controlled, openlabel study and further study is required in a double-blind, placebo-controlled fashion.

In a double-blind crossover study, Noyes and associates (1984) evaluated the efficacy of diazepam and propranolol in 20 patients who met DSM-III criteria for agoraphobia with panic attacks $(n=15)$, and panic disorder $(n=5)$. $\mathrm{Pa}$ tients received either diazepam (median daily dose $30 \mathrm{mg}$ ) or propranolol (median daily dose $240 \mathrm{mg}$ ) for 2 weeks, they were drug-free for a week, then received the opposite treatment for 2 additional weeks (Noyes et al. 1984). The frequency and severity of panic attacks were reduced with diazepam, but not with propranolol. Also, patients with predominantly somatic symptoms responded no better to propranolol than those with predominantly psychological symptoms. Since a placebo group was not included and a crossover design was used, the authors note that the results of this study should be interpreted with caution (Noyes et al. 1984).

In a crossover study with a blind assessor, Munjack and others (1985) evaluated the efficacy of imipramine (doses up to $300 \mathrm{mg} /$ day) and propranolol (doses up to $160 \mathrm{mg} /$ day) in $38 \mathrm{pa}$ tients (only 23 patients completed) who met DSM-III criteria for panic disorder and agoraphobia with panic attacks. The patients were randomly assigned to receive one of the drugs for 7 weeks ( 6 weeks active medication and 1 week tapering). and after one drug-free week, the other drug. Of the patients who completed the study, $83 \%$ of those on propranolol and $78 \%$ receiving imipramine reported mild to moderate improvement. There were no significant differences between the drugs. Problems noted with this study include a crossover design, a large dropout rate $(40 \%)$, the absence of double-blind conditions. and the lack of a placebo control group.

Future studies should consider using a placebo control, higher doses of propranolol, and an extended study phase. The relative efficacy and safety of propranolol alone, combined with a benzodiazepine, a tricyclic, or a monoamine oxidase inhibitor in treating panic disorder and agoraphobia require further study.

\section{Clinical use}

The preceding review clearly demonstrates that propranolol and other $\beta$-blocking agents have not revolutionized the treatment of generalized anxiety disorder. Some reports (Granville-Grossman and Turner 1966: Tyrer and Lader, 1974a, b) have indicated that propranolol was effective for anxiety with predominantly physical symptoms, especially cardiovascular complaints and tremor. Although propranolol may be more effective than placebo in patients with somatic anxiety, it is not as effective as diazepam. One could ask "Is there a role for propranolol in the treatment of generalized anxicty disorder?' The answer is a qualified 'yes' along the following parameters (1) propranolol is an acceptable second line agent when benzodiazepines have failed, especially when anxiety symptoms are predominantly somatic; (2) propranolol may be considered for use in anxiety if tolerance is developing to the benzodiazepines; and (3) since propranolol is not generally sedating at doses used for anxiety and does not appear to impair performance when used acutely for 'performance anxiety'. it may have a role for patients with occupations where sedation is unacceptable.

Although the efficacy of $\beta$-blockers in decreasing panic attacks and phobic avoidance behavior has not been well studied, it does not look promising. Limitations of previous studies may have been subtherapcutic dosages and an inadequate study period. Propranolol's greatest usefulness may be when it is combined with an effective antipanic agent and then specifically to decrease heart rate. Patients with concurrent depression should be closely monitored.

The guidelines for use of propranolol for anxiety disorders begin with evaluation of the patient to prevent untoward events. The treating physician must assess the cardiac status and not administer $\beta$-blockers to patients with bradycardia, heart block, or heart failure. Also, patients with asthma are not candidates for propranolol therapy and those with diabetes should receive propranolol with caution. Patients taking monoamine oxidase inhibitors should not simultaneously receive propranolol and those taking antipsychotics may have hypotensive episodes. If these conditions have been assessed and propranolol therapy is initiated, cer- 
tain side effects may still occur as they do for those patients who use propranolol as an antihypertensive agent. These side effects include fatigue, lightheadedness, nausea, and insomnia. Night terrors or depression have been reported and an index of suspicion for these events is appropriate. Perhaps because of the short half-life of propranolol, these side effects are quickly reversed in most cases by decreasing or stopping the drug. Rapid discontinuation of propranolol should not be done for patients with angina.

Doses ranging from $40-360 \mathrm{mg}$ /day have been used in trials of propranolol, a dose similar to that used to achieve $\beta$-blockade in the treatment of cardiac disease and hypertension (Table 1). A beginning dose of $10 \mathrm{mg}$ q.i.d. is an acceptable way to start treatment and the dose can be titrated upward slowly as symptoms are assessed. As noted earlier, in the dose range used for anxiety disorders there is a wide range of blood levels (Wood et al. 1978), so a range of doses should be expected. Noyes (1982) noted that blood levels may be used to adjust dosage. Because the half-life of propranolol is short, a four times daily dosing strategy is generally recommended. Administration of the medicine at mealtime may reduce the gastric distress of ten noted with propranolol.

The guidelines for the use of other $\beta$-blockers are similar to those for propranolol, with some noted exceptions. First, the anxiolytic effects of other agents have not been as well studied. Since there are specific populations of patients who cannot take propranolol, alternative $\beta$-blockers need to be considered. Metoprolol, a cardioselective agent, is an appropriate choice for diabetic and asthmatic patients who should not take propranolol. In patients with liver disease, the dosage of both propranolol and metoprolol would need adjusting or another $\beta$-blocker selected whose pharmacokinetic profile is not affected by liver disease (i.e., atenolol or nadolol). Because of the high lipid solubility of propranolol and metoprolol, they are the most appropriate $\beta$-blockers when a fast onset of action is desired. Since propranolol is available as a generic drug, prescription cost, as well as efficacy and side effects, would need to be considered in drug selection.

\section{References}

Ahlquist, R.P., A study of the adrenotropic receptor, Am. J Physiology, 153 (1948) 586-600.

American Psychiatric Association, Diagnostic and Statistical Manual of Mental Disorders, 3rd edn., revised (DSM-III-R), American Psychiatric Association, Washington, DC, 1987.

Anderson, D.J., Noyes, R. and Crowe, R.R., A comparison of panic disorder and generalized anxiety disorder, Am. J. Psychiatry, 141 (1984) 572-575.

Ballenger, J.C., Pharmacotherapy of the panic disorders, J. Clin. Psychiatry 47 (1986) 27S-32S.

Becker, A.L., Oxprenolol and propranolol in anxiety states: a double-blind comparative study, S. Afr. Med. J., 50 (1976) 627-629.

Black, I.W., Crowther. A.F., Shanks, R.G. et al., A new adrenergic beta-receptor blocking antagonist, Lancet, i (1964) 1080-1081.

Bonn, J.A., Turner, P. and Hicks, D., Beta-adrenergic receptor blockade with practolol in treatment of anxiety, Lancet, $i$ (1972) 814-815.

Burrows, G.D., Davies, B., Fail, L. et al., A placebo controlled trial of diazepam and oxprenolol for anxiety, Psychopharmacology. 50 (1976) 177-179.

Cannon. W.B., The James - Lange theory of emotions: a critical examination and an alternative theory, Am. J. Psychol., 39 (1927) 106-124.

Charney, D.S. and Heninger, G.R.. Abnormal regulation of noradrenergic function in panic disorder, Arch. Gen. Psychiatry, 43 (1986) 1042-1054.

Charney, D.S., Heninger, G.R. and Breier, A., Noradrenergic function in panic anxiety, Arch. Gen. Psychiatry, 41 (1984) $751-763$.

Cole, J.O., Altesman, R.I. and Weingarten, C.H.. Psychopharmacology update: beta-blocking drugs in psychiatry. McLean Hosp. J., (Winter) (1979) 40-68.

Dommisse, C.S. and Hayes, P.E., Current concepts in clinical therapcutics: anxiety disorders. Part 2, Clin. Pharm., 6 (1987) 196-215.

Fallon, I.K.H., Lloyd, G.G. and Harpin, R.E., Real-life rehearsal with nonprofessional therapists, J. Nerv. Ment. Dis., 196 (1981) 180-184.

FDA, Guidelines for the Clinical Lvaluation of Antianxiety Drugs. DHEW Publication FDA-77-3043, FDA Bureau of Drugs Clinical Guidelines, Washington, DC, 1977.

Gardner, C.R.. Pharmacological studics of the role of serotonin in animal models of anxiety. In: A.R. Green (Ed.), Neuropharmacology of Serotonin, Oxford University Press, New York, 1985, pp. 281-325.

Gengo, F.M. and Green, J.A., Beta-blockers. In: W.E. Evans, J.J. Schentag and W.J. Jusko (Eds.). Applied Pharmacokinetics, 2nd ed., Applied Therapeutics, Spokane, WA, 1986, pp. 735-781.

Goldherg, S.C. and Hamer, R.M., Problems in statistics and experimental design in clinical psychopathology. In: C.E. Walker (Ed.), Handbook of Clinical Psychology, DowJones-Erwin, Homewood. IL, 1983. pp. 75-128.

Gorman, J.M., Levy, G.F., Licbowitz, M.R. et al., Effect of 
acute $\beta$-adrenergic blockade on lactate-induced panic, Arch. Gen. Psychiatry, 40 (1983) 1079-1082.

Granville-Grossman, K.L. and Turner, P., Effect of propranolol on anxiety. Iancet, i (1966) $788-790$.

Greenblatt, D.J. and Shader, R.I., Pharmacotherapy of anxiety with benzodiazepines and $\beta$-adrenergic blockers. In: M.A. Lipton, A. Dimascio and K.F. Killam (Eds.), Psychopharmacology: A Generation of Progress, Raven Press, New York, 1978, pp. $1381 \cdot 1390$

Hallstrom, C.. Treasaden, I., Edwards, J.G. et al., Diazepam. propranolol and their combination in the management of chronic anxiety, Br. J. Psychiatry, 139 (1981) 417-421.

Ilayes, P.E. and Schulz, C.S., Use of beta-adrenergic blocking agents in anxiety disorders and schizophrenia, Pharmacotherapy, 3 (1983) 101-117.

Insel, T.R., Ninan, P.T., Aloi, J. et al., A benzodiazepine receptor-mediated model of anxiety, Arch. Gen. Psychiatry, 41 (1984) $741-750$.

Johnson, G., Singh. B. and Leeman, M., Controlled evaluation of the beta-adrenoreceptor blocking drug oxprenolol in anxiety, Med. J. Aust., 1 (1976) 909-912.

Kathol, R.G.. Noyes, R., Slymen, D.J, et al., Propranolol in chronic anxiety disorders: a controlled study, Arch. Gen. Psychiatry, 37 (1980) 1361-1365.

Kellner, R., Collins, A.C., Shulman, R.S. et al., Short-term antianxiety effects of propranolol $\mathrm{HCl}$. J. Clin. Pharmacol., 14 (1974) $301-304$.

Lands, A.M., Arnold, A.. McAuliff, J.P. et al., Differentiation of receptor systems activated by sympathomimetic amines, Nature, 214 (1967) 597-598.

Liebowitz. M.R., Fyer, A.J., Gorman, J.M. et al., Lactate provocation of panic attacks, Arch. Gen. Psychiatry, 41 (1984) 764-770.

Liebowitz, M.R., Gorman, J.M., Fyer, A. et al., Possible mechanisms for lactate's induction of panic, Am. J. Psychiatry. 143 (1986) 495-502.

Munjack, D.J., Rebal, R., Shaner, R, et al., Imipramine versus propranolol for the treatment of panic attacks: a pilot study, Compr. Psychiatry, 26 (1985) 80-89.

Myers, J.K., Weissman, M.M., Tischler, G.L. et al., Six month prevalence of psychiatric disorders in three communities, Arch. Gen. Psychiatry, 41 (1984) 959-967.

Neese, R.J., Cameron, O.G., Curtis, G.C. et al., Adrenergic function in patients with panic anxiety, Arch. Gen. Psychiatry, 41 (1984) 771-776.

Noyes, R.N., Beta-blocking drugs and anxiety, Psychosomatics, 23 (1982) 155-170.

Noyes, Jr., R., Beta-blocking drugs in anxicty and stress, Psychiatr. Clin. North Am., 8 (1985) 119-132.
Noyes, R., Anderson, D.J., Clancy, J., Crowe, R.R., Slymen, D.J., Ghoneim, M.M. and Hinrichs, I.V., Diazeparm and propranolol in panic disorder and agoraphobia, Arch. Gen. Psychiatry, 41 (1984) 287-292.

Ramsey, I., Greer, S. and Bagley, C., Propranolol in neurotic and thyrotoxic anxiety, Br. J. Psychiatry, 122 (1973) $555-560$.

Redmond. D.F., Alterations in the function of the nucleus locus coeruleus: a possible model for studies of anxiety. In I. Havin and E. Lsdie (Eds.). Animal Models in Psychiatry and Neurology, Pergamon Press. New York, 1977, pp 293-306.

Routledge, P.A. and Shand, P.G., Clinical pharmacokinetics of propranolol, Clin. Pharmacokinet., 4 (1979) 73-90.

Shehi, M. and Patterson, W.M., Treatment of panic attacks with alprazolam and propranolol, Am. J. Psychiatry, 141 (1984) $900-901$

Silverstone, J.T., Some new approaches to the treatment of anxiety, Psychopharmacol. Bull., 10 (1974) 10-11.

Tanna, V.T., Pennigroth, R.P. and Woolson, R.F., Propranolol in the treatment of anxiety neurosis, Compr. Psychiatry, 18 (1977) 319-325.

Tyrer, P.J., Use of beta-blocking drugs in psychiatry and neurology, Drugs, 20 (1980) 300-308.

Tyrer, P.J. and Lader, M.H., Effects of beta-adrenergic blockade with sotalol in chronic anxiety, Clin. Pharmacol. Ther., 14 (1973) 418-426.

Tyrer, P.J. and Lader, M.H., Response to propranolol and diazepam in somatic and psychic anxiety, Br. Med. J., 2 (1974a) 14-16.

Tyrer, P.J. and Lader, M.II., Physiological responses to propranolol and diazepam in chronic anxiety, Br. J. Clin. Pharmacol., 1 (1974b) 387-390.

Weiner, N., Drugs that inhibit adrenergic nerves and block adrenergic receptors. In: A.G. Gilman, L.S. Goodman. T.W. Rall and F. Murad (Eds.), Pharmacological Basis of Therapeutics, 7th ed., MacMillan, New York, 1985, pp. 181-214.

Wheatley, D., Comparative effects of propranolol and chlordiazepoxide in anxiety states, Br. I. Psychiatry, 115 (1969) 1411-1412.

Whitlock. F.A. and Price, J., Use of $\beta$-adrenergic blocking drugs in psychiatry, Drugs. 8 (1974) 109-124.

Wood, A.J.I., Carr, K., Vestal, R.E. et al., Direct measurement of propranolol bioavailability during accumulation to steady state, Br. J. Clin. Pharmacol., 6 (1978) 345-350. 